\title{
Potential use of COX-2-aromatase inhibitor combinations in breast cancer
}

\author{
NJ Bundred*,I and NLP Barnes' \\ 'South Manchester University Hospital, Academic Surgery, Education and Research Centre, Southmoor Road, Manchester M23 9LT, UK
}

Cyclooxygenase-2 (COX-2) is overexpressed in several epithelial tumours, including breast cancer. Cyclooxygenase-2-positive tumours tend to be larger, higher grade, node-positive and HER-2/neu-positive. High COX-2 expression is associated with poor prognosis. Cyclooxygenase-2 inhibition reduces the incidence of tumours in animal models, inhibits the development of invasive cancer in colorectal cancer and reduces the frequency of polyps in familial adenomatous polyposis (FAP). These effects may be as a result of increased apoptosis, reduced angiogenesis and/or proliferation. Studies of COX-2 inhibitors in breast cancer are underway both alone and in combination with other agents. There is evidence to suggest that combining COX-2 inhibitors with aromatase inhibitors, growth factor receptor blockers, or chemo- or radiotherapy may be particularly effective. Preliminary results from combination therapy with celecoxib and exemestane in postmenopausal women with advanced breast cancer showed that the combination increased the time to recurrence. Up to $80 \%$ of ductal carcinomas in situ (DCISs) express COX-2, therefore COX-2 inhibition may be of particular use in this situation. Cyclooxygenase-2 expression correlates strongly with expression of HER-2/neu. As aromatase inhibitors appear particularly effective in patients with HER-2/neu-positive tumours, the combination of aromatase inhibitors and COX-2 inhibitors may be particularly useful in both DCIS and invasive cancer.

British Journal of Cancer (2005) 93(Suppl I), SI0-SI5. doi:I0.I038/sj.bjc.6602690 www.bjcancer.com

(c) 2005 Cancer Research UK

Keywords: COX-2; breast cancer; aromatase inhibitors; combination therapy

Preclinical and clinical evidence shows that prostaglandins play an important role in the growth and development of cancer. Prostaglandin endoperoxide synthase (also called cyclooxygenase; $\mathrm{COX})$ is the rate-limiting enzyme involved in the oxidative transformation of arachidonic acid into prostaglandin $\mathrm{H} 2$, which represents the precursor of several bioactive molecules, including prostaglandin $\mathrm{E}_{2}\left(\mathrm{PGE}_{2}\right)$, prostacyclin and thromboxane. There are at least two isoforms of the COX enzyme: cyclooxygenase-1 (COX-1) and cyclooxygenase-2 (COX-2) (Hla et al, 1999). Both isoforms are found in most human tissues, but while COX-1 is constitutively expressed at low levels (O’Neill and Ford-Hutchinson, 1993), COX-2 expression is an immediate-early response gene that is inducible in response to a variety of stimuli. Cyclooxygenase- 2 is induced by a number of promoters (Herschman, 1996), including stimulation of the epidermal growth factor receptor HER-2/neu (also called c-erbB2) pathway through RAS and the NF $\kappa$ B and NFIL6 inflammation pathways. Overexpression of COX-2 is detected in several epithelial tumours including those of the colon, lung, breast, prostate, skin, oesophagus, pancreas and bladder. New blood vessels surrounding tumours have COX-2 within them (Sano et al, 1995; Chan et al, 1999; Tucker et al, 1999) and, therefore, COX-2 inhibition targets not only the epithelial cells of tumours but also the endothelial cells. In neoplasia, COX-2 promotes tumour angiogenesis (Chang et al, 2004) and inhibits apoptosis (Hsu et al, 2000).

Overexpression of COX-2 in the breast tissue of transgenic mice is associated with increased development of breast tumours, but only after multiple pregnancies (Liu et al, 2001). Breast tissues that

*Correspondence: Professor NJ Bundred;

E-mail: Nigel.J.Bundred@manchester.ac.uk express COX-2 in these transgenic mice have reduced levels of apoptosis compared with normal tissue (Liu et al, 2001). In humans, COX-2 is raised in both ductal carcinoma in situ (DCIS, Half et al, 2002) and invasive breast cancer (Spizzo et al, 2003; Boland et al, 2004; Figure 1) and appears to be associated with higher proliferation, lower apoptosis and increased new blood vessel formation (Kirkpatrick et al, 2001; Boland et al, 2004). Indeed, a large study of 1576 patients with invasive breast cancer demonstrated that COX-2 was expressed at high levels in over $50 \%$ of patients and these patients had a significantly worse disease-free survival compared with patients whose tumours expressed lowlevels of, or absent, COX-2 (Ristimaki et al, 2002). Studies with celecoxib, a selective COX-2 inhibitor, in an HER2/neu-induced breast cancer model in transgenic mice have revealed that celecoxib reduced the incidence of mammary tumours and lowered mammary $\mathrm{PGE}_{2}$ levels by $50 \%$ (Howe et al, 2002; LanzaJacoby et al, 2003).

In colorectal cancer and familial adenomatous polyposis (FAP), COX-2 inhibition has been shown to inhibit the development of invasive cancer and reduce the frequency of polyp formation (Giardiello et al, 1993; Steinbach et al, 2000; Phillips et al, 2002; Asano and McLeod, 2004). In a pivotal study, 6 months of treatment with celecoxib, $400 \mathrm{mg}$ b.i.d. (twice the licensed antiarthritis dose) significantly prevented polyp formation compared with placebo (Phillips et al, 2002). Studies have also suggested that combinations of COX-2 inhibitors with an epidermal growth factor receptor (EGFR) inhibitor have synergistic benefits in animal models of FAP (min mouse) (Torrance et al, 2000). Other studies have shown a potential benefit of COX-2 inhibitors in non-small-cell lung cancer (Altorki et al, 2003). 

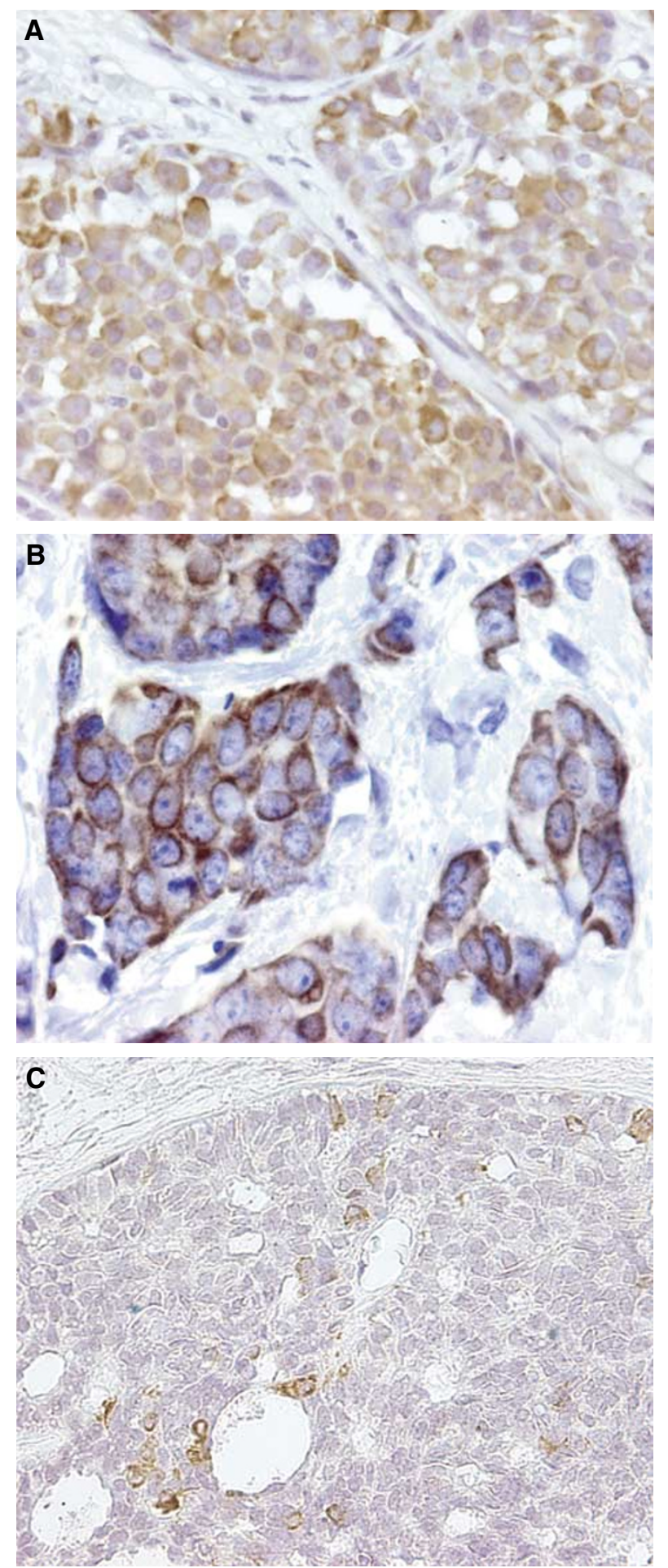

Figure I COX-2 is strongly expressed in the cell cytoplasm in (A) ductal carcinoma in situ and $(\mathbf{B})$ invasive breast cancer. For comparison, $(\mathbf{C})$ shows COX-2 as negatively expressed in a ductal carcinoma in situ with little staining.

Work from our laboratory (Barnes et al, 2003) and others (Masferrer et al, 2000; Fu et al 2004) has clearly shown that COX-2 inhibition with celecoxib prevents the growth of lung, colon and breast human tumour xenografts in nude mice (Figure 2). The growth of both MDA-MB231 cells, an oestrogen receptor (ER)negative, EGFR-positive RAS transformed breast cancer cell line and
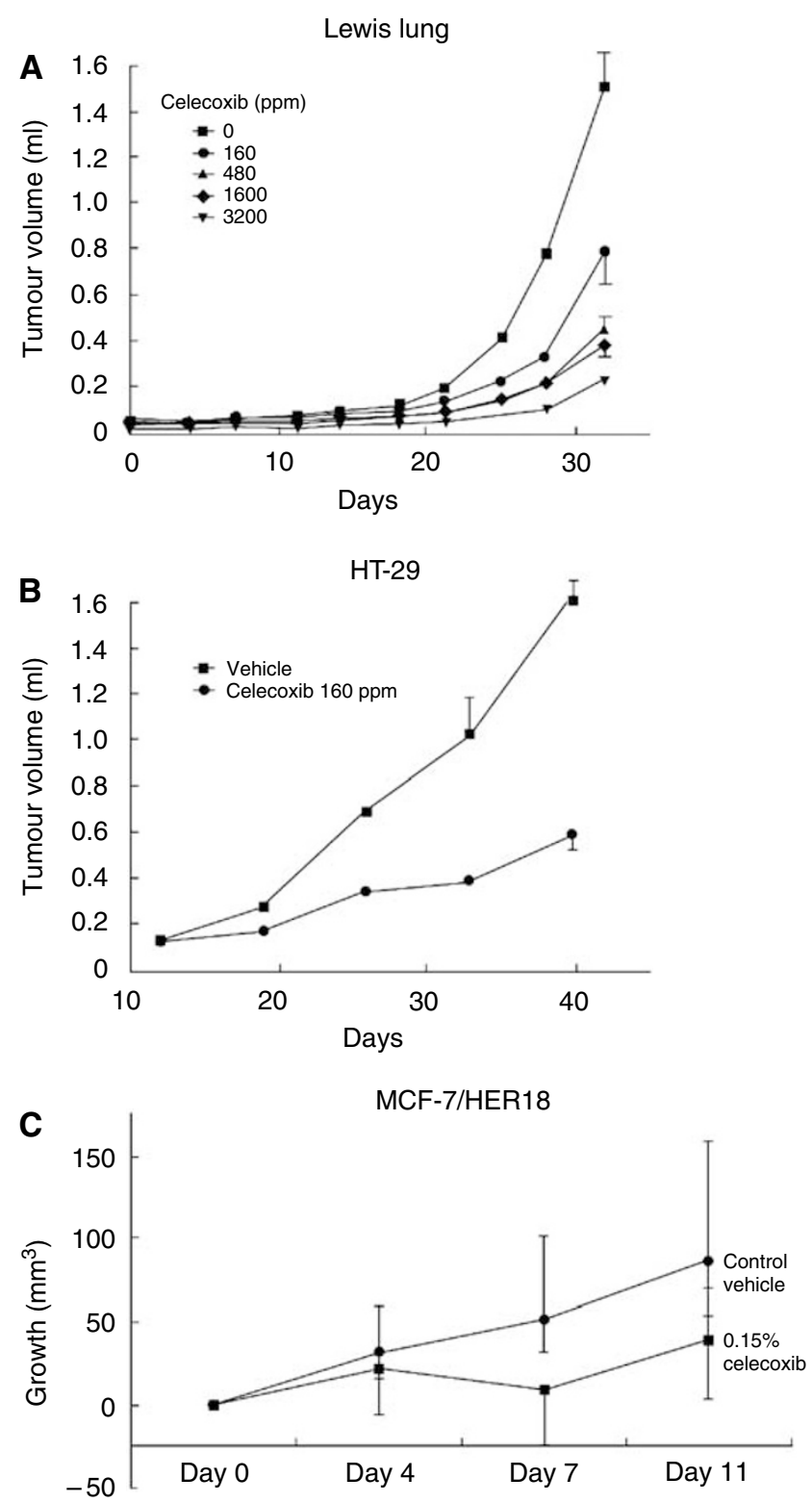

Figure 2 Celecoxib, a COX-2 inhibitor, slows growth of cancer cell lines derived from (A) lung, (B) colon and (C) breast when xenografted into mice (Masferrer et al, 2000; Barnes et al, 2003). (C) Median tumour growth, bars $=$ interquartile range. Figures $(\mathbf{A})$ and $(\mathbf{B})$ reproduced with permission from Masferrer et al (2000).

HER18 cells, an ER-positive, HER-2/neu transfected MCF-7 breast cancer cell line, were both markedly inhibited by celecoxib in a xenograft model (Figure 2C; Barnes et al, 2003). These data suggest that celecoxib may help to prevent ER-negative cancers and be of value in HER-2/neu-positive breast cancer. Studies of COX-2 inhibitors in breast cancer are underway as adjuvant therapy.

\section{MECHANISMS OF ACTION OF COX-2 INHIBITORS}

There are three potential anticancer mechanisms for COX-2 inhibition, it may

- inhibit proliferation in epithelial cells,

- increase apoptosis,

- reduce angiogenesis. 


\section{Proliferation}

Data from studies that have looked at COX-2 expression and proliferation markers, such as Ki67, have shown a strong correlation between the presence of COX-2 and increased proliferation (Ferrandina et al, 2003; Boland et al, 2004), but as yet no data have been published to show that inhibition of COX-2 leads to a lower proliferative rate in tumours in vivo.

\section{Apoptosis}

Several lines of study have indicated that COX-2 inhibition may increase apoptosis. In a study investigating the effect of celecoxib on prostate cancer cell lines, AKT phosphorylation was significantly inhibited by celecoxib leading to increased caspase-3 activation and apoptosis (Hsu et al, 2000). Celecoxib has also recently been shown to decrease the activation of the transcription factor $\mathrm{NF} \kappa \mathrm{B}$ in lung cancer cell lines (Shishodia et al, 2004); celecoxib was found to interfere with the tumour necrosis factoralpha $(\mathrm{TNF}-\alpha)$ induced interaction of AKT with IKK (the protein kinase required for $\mathrm{NF} \kappa \mathrm{B}$ activation). $\mathrm{NF} \kappa \mathrm{B}$ regulates a wide spectrum of genes including those involved in the immune response, cell proliferation and apoptosis.

Since HER-2/neu regulates AKT phosphorylation downstream (Nicholson et al, 2003), it is certainly conceivable that inhibiting COX-2 may affect this pathway upstream leading to increased apoptosis. As previously mentioned, in COX-2 transgenic mice, mouse mammary tissue had significantly less apoptosis than normal tissue and had a reduced expression of $\mathrm{Bcl}_{2}$-XL and BAX (Liu et al, 2001), which are both proapoptotic proteins. Also, it may be that COX-2 affects the mitochondrial pathway (an intrinsic pathway that induces apoptosis in the normal breast).

\section{Angiogenesis}

Celecoxib inhibition of COX-2 is one of the most potent antiangiogenic mechanisms currently available to the clinician. Multiple publications from Dubois and co-workers have indicated that COX-2 inhibition leads to a reduced secretion of vascular endothelial growth factor (VEGF) and in vitro reduced endothelial tube formation in matrigel (Tsujii et al, 1998; Sawaoka et al, 1999; Woods et al, 2003). Celecoxib has been shown to inhibit basic fibroblast growth factor-induced angiogenesis in vivo using a rat corneal angiogenesis model (Masferrer et al, 2000). Furthermore, lung cancer xenografts showed decreased vascularity when implanted into COX-2 null mice (Williams et al, 2000). Chang et al have shown that COX-2 regulates angiogenesis in normal mammary tissue via $\mathrm{PgE}_{2}$ production; therefore, inhibition of angiogenesis by COX-2 inhibitors has the potential for chemoprevention of breast cancer.

In invasive breast cancer, COX-2 expression has been shown to correlate with the levels of angiogenesis (measured by CD-31 staining) in tumours (Davies et al, 2003). In addition, preliminary results, from a randomised trial using celecoxib given for 2 weeks before surgery compared with no treatment, have shown a significant fall in serum VEGF levels after 14 days of treatment, indicating that celecoxib may be useful in preventing angiogenesis and lymphovascular spread at around the time of surgery (O-Donoghue et al, 2004). Therefore, there is increasing interest in examining COX-2 inhibitors in breast cancer, alone or in combination with other agents, to determine the overall effect on prevention, recurrence after early breast cancer treatment and induction of endocrine response in advanced disease. The antiangiogenic and proapoptotic effects seen indicate that the drug may potentially be effective in both ER-positive and -negative tumours.

\section{INTEGRATING COX-2 INHIBITION INTO BREAST CANCER TREATMENT}

With preclinical studies demonstrating an effect of COX-2 inhibition on tumour growth in animal models and COX-2 being involved in breast carcinogenesis, COX-2 inhibition is being considered for inclusion into breast cancer therapy. It is likely that COX-2 inhibitors will be used as combination therapy with hormonal agents, such as an aromatase inhibitor to decrease aromatisation and angiogenesis, or with growth factor receptor blockers, such as trastuzumab (Herceptin ${ }^{\mathbb{R}}$ ), to synergise blockade of the HER-2/neu RAS pathway inhibition. Also, COX-2 inhibition has been shown in animal models to make tumours significantly more chemo- and radio-sensitive. Therefore, several combinations are being explored in current clinical trials.

Rofecoxib was recently withdrawn from the market due to an increased risk of cardiovascular events found in both the Vioxx Gastrointestinal Outcomes Research (VIGOR) study and the recent Adenomatous Polyp Prevention on Vioxx (APPROVe) trial. The cardiovascular safety of celecoxib is currently being examined following results from one trial, the Adenoma Prevention with Celecoxib (APC) trial, which found patients taking 400 and $800 \mathrm{mg} \mathrm{day}^{-1}$ of celecoxib had a 2.5- to 3.4-fold increased risk of major fatal or nonfatal cardiovascular events vs placebo (average duration of treatment 33 months). The use of celecoxib in this trial has now been suspended. Data suggest that any cardiovascular concerns may be related to long-term use ( $>12$ months) of celecoxib. By contrast, no increased risk has been seen for celecoxib $400 \mathrm{mg}^{-1 a y}{ }^{-1} v$ s placebo in two separate long-term studies, the Prevention of Spontaneous Adenomatopus Polyps (PreSAP) trial and the Alzheimer's Disease Anti-inflammatory Prevention Trial (ADAPT). Additionally, no cardiovascular concerns have been noted in over 40000 celecoxib-treated patients. Several trials investigating celecoxib in preinvasive, invasive and metastatic breast cancer are ongoing as shown in Table 1.

It is recommended that patients with a history of ischaemic heart disease or cardiovascular disease should not receive a COX-2 inhibitor.

\section{Combining COX-2 inhibitors with aromatase inhibitors}

Brueggemeier et al $(1999,2001)$ looked at the levels of aromatase (cyp19) and cox-2 gene expression in breast tissue using the semiquantative, reverse transcriptase polymerase chain reaction (RT-PCR) technique. High levels of cox-2 mRNA expression led to increased levels of $\mathrm{PGE}_{2}$, which in turn increased cyp19 expression. This was achieved through increased intracellular cAMP levels and activation of the cyp19 promoter 2, resulting in increased aromatase activity (Richards et al, 2002). Zhao et al (1996) have shown that the level of aromatase activity is markedly increased in the presence of $\mathrm{PGE}_{2}$. Other workers have indicated that the $\mathrm{PGE}_{2}$ and cytokines such as interleukin- 6 or TNF- $\alpha$ regulate aromatase activity in tumour cells (Michael et al, 1997; Brueggemeier et al, 2001). Therefore, inhibition of $\mathrm{PGE}_{2}$ by COX-2 inhibitors may inhibit aromatase activity and, when combined with aromatase inhibitors, reduce tumour recurrence by inhibiting a common target: aromatase.

Pesenti et al (2001) provided preclinical data from a rodent model in which celecoxib combined with exemestane significantly inhibited the growth of mammary tumours compared with vehicle or celecoxib alone and slowed the growth of established tumours at 5 weeks (Figure 3). Results of a small, randomised, phase II study in postmenopausal women $(n=111)$ with advanced breast cancer treated with exemestane, $25 \mathrm{mg}$ q.d. and celecoxib, $400 \mathrm{mg}$ p.o. b.i.d. indicated a longer time to breast cancer recurrence with no additional side effects from the use of celecoxib and exemestane (Dirix et al, 2003). Pharmacogenomic studies are planned to 
Table I Overview of current clinical trials of COX-2 inhibitors in the treatment of breast cancer

\section{Trial}

UK multicentre phase III trial of exemestane and COX-2 inhibition in ER-positive DCIS

Neoadjuvant celecoxib plus fluorouracil, epirubicin and cyclophosphamide for the treatment of locally advanced breast cancer

KUMC-HSC-89 19-02: phase II chemoprevention study of celecoxib in premenopausal women at high risk of ER-negative breast cancer

Italian breast cancer trial of celecoxib in combination with weekly taxotere and capecitabine as first-line therapy in advanced breast cancer

ICCG: pilot study, DNA microarray analysis of human breast cancer before and after treatment with COX-2 inhibitors: search for biomarkers

Royal Infirmary phase III, randomised, placebo-controlled trial of celecoxib in patients with metastatic breast cancer

Phase I trial of vinorelbine and celecoxib in treating women with relapsed or metastatic breast cancer

MSKCC-03027: phase I, randomised study of celecoxib in postmenopausal women with invasive breast cancer undergoing surgery, to look for suppression of aromatase activity and biomarkers of effect

CALGB-40 105: phase II, randomised study of celecoxib in women with metastatic or recurrent breast cancer, comparing low dose to high-dose treatment. Further recruitment of patients to celecoxib is under discussion. $\mathrm{NCl-04-C-0044:} \mathrm{phase} \mathrm{II} \mathrm{study} \mathrm{of} \mathrm{exemestane} \mathrm{alone} \mathrm{or} \mathrm{in} \mathrm{combination} \mathrm{with} \mathrm{celecoxib} \mathrm{in} \mathrm{postmenopausal}$ women at high risk for invasive breast cancer

\section{Principal investigator (Ref)}

Bundred (National Cancer Research Network, 2005) Chow et al (2003)

Fabian (National Cancer Institute, 2005a)

Gasparini et al (2003)

Hupperets, Wagstaff (Gasparini et al, 2003)

McMillan (Gasparini et al, 2003)

Overmoyer (Clinical Trials.gov)

Port, Hudis (National Cancer Institute, 2005b)

Shapiro (National Cancer Institute, 2005c)

Zujewski (National Cancer Institute, 2005d)

$\mathrm{DCIS}=$ ductal carcinoma in situ; $\mathrm{ER}=$ oestrogen receptor.

determine the mechanism of action of increased inhibition with celecoxib.

\section{Other potential COX-2 combinations}

Trastuzumab Several studies have shown that up to $80 \%$ of DCISs express COX-2 and that its expression correlates strongly with expression of HER-2/neu in the same tumours (Half et al, 2002; Tan et al, 2004). Cyclooxygenase-2 expression has been associated with higher grade ER-negative, HER-2/neu-positive tumours and COX-2-positive tumours have been linked with a significantly worse overall survival (Ristimaki et al, 2002). Therefore, in the group of women with HER-2/neu-positive tumours, it may be beneficial to use COX-2 inhibition in combination with an agent such as trastuzumab (Herceptin ${ }^{\circledR}$ ), which blocks the extracellular domain of the HER-2/neu receptor and inhibits RAS and MAPkinase signalling. A phase II, randomised trial of trastuzumab, with or without celecoxib, in a series of 12 patients with metastatic breast cancer who had previously progressed after trastuzumab-based treatments, found that there was no treatment effect, although the drug combination was well tolerated (Dang et al, 2004). This study consisted only of patients who had been pretreated with trastuzumab. The effect on treatment-naïve patients is still unknown and being investigated in an ongoing trial.

Chemotherapy Blocking $\mathrm{PGE}_{2}$ production by inhibiting COX-2 has recently been shown to have effects upstream of the HER-2/ neu pathway resulting in decreased HER-2/neu protein levels and increased sensitivity of cancer cells to chemotherapeutic treatment (Benoit et al, 2004). Coadministration of celecoxib and cyclophosphamide was significantly more effective in preventing growth of Lewis lung cancer tumours than either drug alone (Koki et al, 1999) and studies of combination of several chemotherapy agents with celecoxib have indicated that celecoxib lowers the threshold of sensitivity to chemotherapy (Altorki et al, 2003; Nakata et al, 2004). In Europe, a phase III, multicentre, double-blind, randomised trial of celecoxib $v s$ placebo following chemotherapy (REACT Trial; Current Controlled Trials) has been initiated in primary breast cancer patients, although the protocol for this study is currently under review. Primary breast cancer patients who have completed surgery, neoadjuvant chemotherapy and radiotherapy are randomised to receive celecoxib, $400 \mathrm{mg}$ twice a day for 2 years, or placebo, with exemestane given to all ER-positive patients for 5 years. This study aims to determine

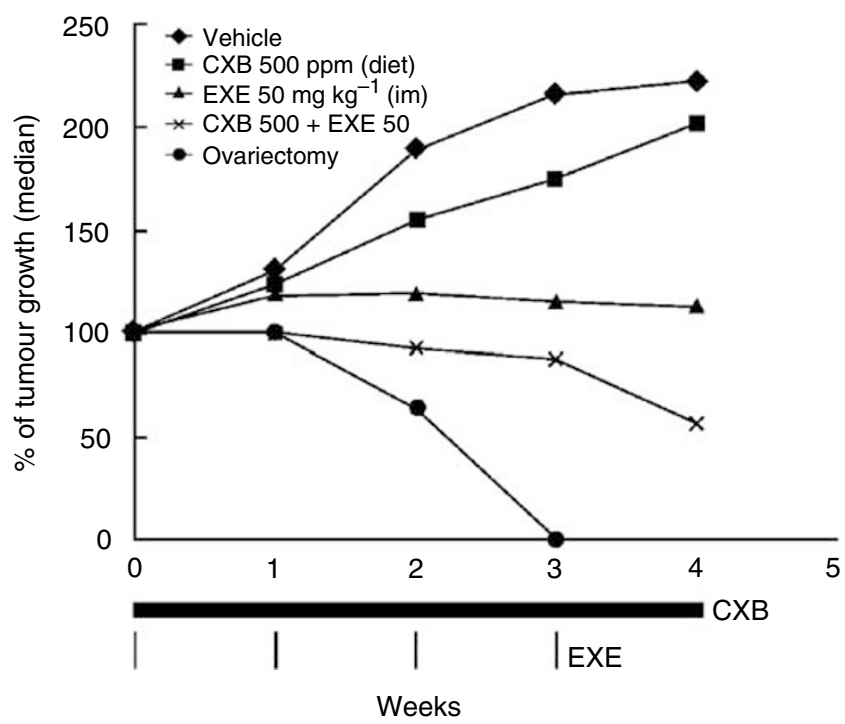

Figure 3 Combined celecoxib (CXB) and exemestane (EXE), reduces mammary tumour growth in a rodent model more effectively than either therapy alone (Pesenti et al, 200I).

whether the addition of celecoxib improves overall survival in patients at high risk of recurrence.

\section{COX-2 and aromatase inhibition in DCIS}

The high expression of HER-2/neu and COX-2 in DCIS (particularly high grade) combined with the clear correlation between proliferation and COX-2 expression in DCIS (Boland et al, 2004) has stimulated interest in the use of COX-2 inhibitors to prevent recurrent DCIS in ER-positive and -negative disease. Clear evidence from both the ATAC (Baum et al, 2003) study and the Letrozole/Tamoxifen Neoadjuvant Trial has suggested that aromatase inhibition is the treatment of choice in HER-2/neupositive, ER-positive tumours (Ellis et al, 2001). In a 3-month neoadjuvant study, letrozole was 28 times more likely than tamoxifen to induce response in HER-2/neu-positive, ER-positive, invasive breast cancer, with $88 \%$ of patients responding to the aromatase inhibitor and $21 \%$ to tamoxifen. By contrast, in 
HER-2/neu-negative, ER-positive patients, 54\% responded to letrozole and $42 \%$ to tamoxifen (Ellis et al, 2001). The recently published results of the ATAC trial comparing anastrozole with tamoxifen demonstrated a reduction in recurrence of over $8 \%$ in ER-positive, $\mathrm{PR}$-negative patients (predominantly HER-2/neu-positive group) compared with a $4 \%$ difference in the ER-positive, PR-positive group (Baum et al, 2003; Dowsett et al, 2003). This would suggest that aromatase inhibition would be more beneficial in those patients who express HER-2/neu. The mechanism for this is not fully clear; however, tamoxifen translocates the ER complex to the nucleus, opening up DNA and allowing some agonist activity with coactivators, whereas aromatase inhibition does not (Ellis et al, 2001). Therefore, the HER-2/neu pathway cannot affect the coactivators or corepressors that have been induced by translocating the ER to the nucleus. There is evidence that expression of AIB (amplified in breast cancer 1), a nuclear coactivator complex, is upregulated in HER-2/neu-positive tumours and is associated with endocrine resistance (Osborne et al, 2002). Preventing translocation of the ER to the nucleus lowers oestrogen levels in the breast and tumour tissue and lowers AIB levels, therefore decreasing endocrine resistance (Shou et al, 2002).

With $70 \%$ of DCISs expressing HER-2/neu (Tan et al, 2002), it is possible that combining COX-2 inhibition with an aromatase inhibitor in DCIS patients will reduce recurrence in both the ipsilateral and contralateral breast. Early, placebo-controlled studies in DCIS are assessing the effects of administering celecoxib for 14 days on proliferation, apoptosis and angiogenesis in the presurgical setting. Studies in the USA are looking at the effect of celecoxib on ER-negative DCIS in this setting and in the UK on ER-positive DCIS. In addition, trials have been proposed using adjuvant celecoxib in ER-negative DCIS to determine whether it prevents recurrence after wide local excision. Given the lack of chemopreventive agents that can be used to prevent ER-negative breast cancer or used as adjuvant therapy in ER-negative breast cancer, there is a potential primary role for celecoxib in this setting.

\section{CONCLUSIONS}

Animal studies and early patient trials have shown encouraging results for the use of COX-2 inhibition alone and/or with other therapeutic agents in breast cancer and other oncology settings, including colorectal cancer and non-small-cell lung cancer. In particular, combining an aromatase inhibitor with a COX-2 inhibitor has been hypothesised to reduce overall disease recurrence by inhibiting a common target, aromatase. A number of trials are ongoing to test this hypothesis further and results are awaited with interest.

\section{REFERENCES}

Altorki NK, Keresztes RS, Port JL, Libby DM, Korst RJ, Flieder DB, Ferrara CA, Yankelevitz DF, Subbaramaiah K, Pasmantier MW, Dannenberg AJ (2003) Celecoxib, a selective cyclo-oxygenase-2 inhibitor, enhances the response to preoperative paclitaxel and carboplatin in early-stage nonsmall-cell lung cancer. J Clin Oncol 21: 2645-2650

Asano TK, McLeod RS (2004) Nonsteroidal anti-inflammatory drugs and aspirin for the prevention of colorectal adenomas and cancer: a systematic review. Dis Colon Rectum 47: 665-673

Barnes NLP, Warnberg F, White D, Anderson E, Bundred NJ (2003) Cyclooxygenase-2 inhibition and tumour growth: celecoxib increases apoptosis in HER2 positive cell lines. Breast Cancer Res Treat 82(suppl 1) (Abstract 667)

Baum M, Buzdar A, Cuzick J, Forbes J, Houghton J, Howell A, Sahmoud T, The ATAC (Arimidex, Tamoxifen Alone or in Combination) Trialists Group (2003) Anastrozole alone or in combination with tamoxifen vs tamoxifen alone for adjuvant treatment of postmenopausal women with early-stage breast cancer: results of the ATAC (Arimidex, Tamoxifen Alone or in Combination) trial efficacy and safety update analyses. Cancer 98: $1802-1810$

Benoit V, Relic B, Leval Xd X, Chariot A, Merville MP, Bours V (2004) Regulation of HER-2 oncogene expression by cyclooxygenase- 2 and prostaglandin E2. Oncogene 23: $1631-1635$

Boland GP, Butt IS, Prasad R, Knox WF, Bundred NJ (2004) COX-2 expression is associated with an aggressive phenotype in ductal carcinoma in situ. Br J Cancer 90: 423-429

Brueggemeier RW, Quinn AL, Parrett ML, Joarder FS, Harris RE, Robertson FM (1999) Correlation of aromatase and cyclooxygenase gene expression in human breast cancer specimens. Cancer Lett 140: 27-35

Brueggemeier RW, Richards JA, Joomprabutra S, Bhat AS, Whetstone JL (2001) Molecular pharmacology of aromatase and its regulation by endogenous and exogenous agents. J Steroid Biochem Mol Biol 79: 75-84

Chan G, Boyle JO, Yang EK, Zhang F, Sacks PG, Shah JP, Edelstein D, Soslow RA, Koki AT, Woerner BM, Masferrer JL, Dannenberg AJ (1999) Cyclooxygenase-2 expression is up-regulated in squamous cell carcinoma of the head and neck. Cancer Res 59: 991-994

Chang SH, Liu CH, Conway R, Han DK, Nithipatikom K, Trifan OC, Lane TF, Hla T (2004) Role of prostaglandin E2-dependent angiogenic switch in cyclooxygenase 2-induced breast cancer progression. Proc Natl Acad Sci USA 101: $591-596$

Chow LW, Toi M, Takebayashi Y (2003) Neoadjuvant celecoxib and 5-fluorouracil/epirubicin/cyclophosphamide (FEC) for the treatment of locally advanced breast cancer (LABC). Proc Am Soc Clin Oncol 22: 82 (Abstract 327)

Clinical Trials.gov Vinorelbine and celecoxib in treating women with relapsed or metastatic breast cancer, http://www.clinicaltrials.gov/ct/ show/NCT00075673, last viewed February 2005

Current Controlled Trials A phase III multicentre double blind randomised trial of celecoxib $v s$ placebo following chemotherapy in primary breast cancer patients, http://controlled-trials.com/isrctn/trial///0/48254013. html, last viewed February 2005

Dang CT, Dannenberg AJ, Subbaramaiah K, Dickler MN, Moasser MM, Seidman AD, D'Andrea GM, Theodoulou M, Panageas KS, Norton L, Hudis CA (2004) Phase II study of celecoxib and trastuzumab in metastatic breast cancer patients who have progressed after prior trastuzumab-based treatments. Clin Cancer Res 10: 4062-4067

Davies G, Salter J, Hills M, Martin LA, Sacks N, Dowsett M (2003) Correlation between cyclooxygenase-2 expression and angiogenesis in human breast cancer. Clin Cancer Res 9: 2651-2656

Dirix LY, Ignacio J, Nag S (2003) Final results from an open-label, multicenter, controlled study of exemestane $+/-$ celecoxib in postmenopausal women with advanced breast cancer (ABC) progressed on tamoxifen (T). Proc Am Soc Clin Oncol 22: 20 (Abstract 77)

Dowsett M, on behalf of the ATAC Trialists Group (2003) Analysis of time to recurrence in the ATAC (arimidex, tamoxifen, alone or in combination) trial according to estrogen and progesterone receptor status. Breast Cancer Res Treat 82(Suppl 1): 6 (Abstract 4)

Ellis MJ, Coop A, Singh B, Mauriac L, Llombert-Cussac A, Janicke F, Miller WR, Evans DB, Dugan M, Brady C, Quebe-Fehling E, Borgs M (2001) Letrozole is more effective neoadjuvant therapy than tamoxifen for ErbB1- and ErbB-2-positive, estrogen receptor-positive primary breast cancer: evidence from a phase III randomized trial. J Clin Oncol 19: 3808-3816

Ferrandina G, Ranelletti FO, Legge F, Lauriola L, Salutari V, Gessi M, Testa AC, Werner U, Navarra P, Tringali G, Battaglia A, Scambia G (2003) Celecoxib modulates the expression of cyclooxygenase-2, ki67, apoptosis-related marker, and microvessel density in human cervical cancer: a pilot study. Clin Cancer Res 9: 4324-4331

Fu SL, Wu YL, Zhang YP, Qiao MM, Chen Y (2004) Anti-cancer effects of COX-2 inhibitors and their correlation with angiogenesis and invasion in gastric cancer. World J Gastroenterol 10: 1971-1974

Gasparini G, Longo R, Sarmiento R, Morabito A (2003) Inhibitors of cyclo-oxygenase 2: a new class of anticancer agents? Lancet Oncol 4: $605-615$

Giardiello FM, Hamilton SR, Krush AJ, Piantadosi S, Hylind LM, Celano P, Booker SV, Robinson CR, Offerhaus GJ (1993) Treatment of colonic and rectal adenomas with sulindac in familial adenomatous polyposis. $N$ Engl J Med 328: $1313-1316$ 
Half E, Tang XM, Gwyn K, Sahin A, Wathen K, Sinicrope FA (2002) Cyclooxygenase expression in human breast cancers and adjacent ductal carcinoma in situ. Cancer Res 62: 1676-1681

Herschman HR (1996) Prostaglandin synthase 2. Biochim Biophys Acta 1299: $125-140$

Hla T, Bishop-Bailey D, Liu CH, Schaefers HJ, Trifan OC (1999) Cyclooxygenase-1 and -2 isoenzymes. Int J Biochem Cell Biol 31: $551-557$

Howe LR, Subbaramaiah K, Patel J, Masferrer JL, Deora A, Hudis C, Thaler HT, Muller WJ, Du B, Brown AM, Dannenberg AJ (2002) Celecoxib, a selective cyclooxygenase 2 inhibitor, protects against human epidermal growth factor receptor 2 (HER-2)/neu-induced breast cancer. Cancer Res 62: $5405-5407$

Hsu AL, Ching TT, Wang DS, Song X, Rangnekar VM, Chen CS (2000) The cyclooxygenase- 2 inhibitor celecoxib induces apoptosis by blocking Akt activation in human prostate cancer cells independently of Bcl-2. J Biol Chem 275: $11397-11403$

Kirkpatrick K, Ogunkolade W, Elkak AE (2001) The association between cyclo-oxygenase- 2 expression and cell proliferation and angiogenesis in human breast cancer. Breast Cancer Res 3(Suppl 1): A37

Koki AT, Leahy KM, Masferrer JL (1999) Potential utility of COX-2 inhibitors in chemoprevention and chemotherapy. Expert Opin Invest Drugs 8: $1623-1638$

Lanza-Jacoby S, Miller S, Flynn J, Gallatig K, Daskalakis C, Masferrer JL, Zweifel BS, Sembhi H, Russo IH (2003) The cyclooxygenase-2 inhibitor, celecoxib, prevents the development of mammary tumors in HER-2/neu mice. Cancer Epidemiol Biomarkers Prev 12: 1486-1491

Liu CH, Chang SH, Narko K, Trifan OC, Wu MT, Smith E, Haudenschild C, Lane TF, Hla T (2001) Overexpression of cyclooxygenase-2 is sufficient to induce tumorigenesis in transgenic mice. J Biol Chem 276: 18563-18569

Masferrer JL, Leahy KM, Koki AT, Zweifel BS, Settle SL, Woerner BM, Edwards DA, Flickinger AG, Moore RJ, Seibert K (2000) Antiangiogenic and antitumor activities of cyclooxygenase-2 inhibitors. Cancer Res 60: $1306-1311$

Michael MD, Michael LF, Simpson ER (1997) A CRE-like sequence that binds CREB and contributes to cAMP-dependent regulation of the proximal promoter of the human aromatase P450 (CYP19) gene. Mol Cell Endocrinol 134: 147-156

Nakata E, Mason KA, Hunter N (2004) Potentiation of tumor response to radiation or chemoradiation by selective cyclooxygenase- 2 enzyme inhibitors. Int J Radiat Oncol Biol Phys 58: 369-375

National Cancer Institute (2005a) Phase II chemoprevention study of celecoxib in premenopausal women at high risk for estrogen receptornegative breast cancer, http://cancer.gov/search/ViewClinicalTrials.aspx? cdrid $=271935 \&$ version $=$ HealthProfessional\&protocolsearchid $=1103726$, last viewed February 2005

National Cancer Institute (2005b) Phase I randomized study of celecoxib in postmenopausal women with invasive breast cancer undergoing surgery, http://cancer.gov/clinicaltrials/MSKCC-03027\#AlternateTitle_ CDR0000329919, last viewed February 2005

National Cancer Institute (2005c) Phase II randomized study of celecoxib in women with metastatic or recurrent breast cancer, http://cancer.gov/search/ ViewClinicalTrials.aspx $?$ cdrid $=256905 \&$ version $=$ HealthProfessional $\&$ protocolsearchid $=1103726$, last viewed February 2005

National Cancer Institute (2005d) Phase II study of exemestane alone or in combination with celecoxib in postmenopausal women at high risk for invasive breast cancer, http://cancer.gov/search/ViewClinicalTrials.aspx? cdrid $=367245 \&$ version $=$ HealthProfessional\&protocolsearchid $=1103726$, last viewed February 2005

National Cancer Research Network (2005) ERISAC Effects of exemestane and COX-2 inhibition on oestrogen receptor positive ductal carcinoma in situ, http://www.ncrn.org.uk/portfolio/data.asp?ID = 1367, last viewed February 2005

Nicholson KM, Streuli CH, Anderson NG (2003) Autocrine signalling through erbB receptors promotes constitutive activation of protein kinase B/Akt in breast cancer cell lines. Breast Cancer Res Treat 81: 117-128

O-Donoghue GT, Roche-Nagloe G, Connolly EM, Harmey J, BouchierHayes D (2004) Selective COX-2 inhibition attenuates the perioperative increase of the tumour enhancing proangiogenesis cytokine VEGF in human breast cancer. Br J Surg 91(Suppl 1): 43

O'Neill GP, Ford-Hutchinson AW (1993) Expression of mRNA for cyclooxygenase-1 and cyclooxygenase- 2 in human tissues. FEBS Lett 330: $156-160$
Osborne CK, Bardou V-J, Hilsenbeck SG, Fuqua SA, Hopp T, Chamness G, Wong J, Schiff R, Allred C, Clark G (2002) The estrogen receptor coactivator AIB1 (SRC3) in combination with HER-2 is a prognostic and predictive marker in patients with breast cancer. Proc Am Soc Clin Oncol 21: 33a (Abstract 129)

Pesenti E, Masferrer JL, di Salle E (2001) Effect of exemestane and celecoxib alone or in combination on DMBA-induced mammary carcinoma in rats. Breast Cancer Res 69: 288 (Abstract 445)

Phillips RK, Wallace MH, Lynch PM, Hawk E, Gordon GB, Saunders BP, Wakabayashi N, Shen Y, Zimmerman S, Godio L, Rodrigues-Bigas M, Su LK, Sherman J, Kelloff G, Levin B, Steinbach G, FAP Study Group (2002) A randomised, double blind, placebo controlled study of celecoxib, a selective cyclooxygenase 2 inhibitor, on duodenal polyposis in familial adenomatous polyposis. Gut 50: $857-860$

Richards JA, Petrel TA, Brueggemeier RW (2002) Signalling pathways regulating aromatase and cyclooxygenases in normal and malignant breast cells. J Steroid Biochem Mol Biol 80: 203-212

Ristimaki A, Sivula A, Lundin J, Lundin M, Salminen T, Haglund C, Joensuu H, Isola J (2002) Prognostic significance of elevated cyclooxygenase-2 expression in breast cancer. Cancer Res 62: 632-635

Sano H, Kawahito Y, Wilder RL, Hashiramoto A, Mukai S, Asai K, Kimura S, Kato H, Kondo M, Hla T (1995) Expression of cyclooxygenase-1 and -2 in human colorectal cancer. Cancer Res 55: 3785-3789

Sawaoka H, Tsuji S, Tsujii M, Gunawan ES, Sasaki Y, Kawano S, Hori M (1999) Cyclooxygenase inhibitors suppress angiogenesis and reduce tumor growth in vivo. Lab Invest 79: 1469-1477

Shishodia S, Koul D, Aggarwal BB (2004) Cyclooxygenase (COX)-2 inhibitor celecoxib abrogates TNF-induced NF-kappa B activation through inhibition of activation of I kappa B alpha kinase and Akt in human non-small cell lung carcinoma: correlation with suppression of COX-2 synthesis. J Immunol 173: 2011-2022

Shou J, Massarweh S, Mohsin SK, Brown PH, Wakeling AE, Ali AS, Osborne K, Schiff R (2002) Blockade of the estrogen receptor/growth factor crosstalk implicated in breast cancer tamoxifen resistance using a selective EGFR TK inhibitor. Program and Abstracts of the 25th San Antonio Breast Cancer Symposium, December 11-14, 2002, San Antonio, Texas (Abstract 246)

Spizzo G, Gastl G, Wolf D, Gunsilius E, Steurer M, Fong D, Amberger A, Margreiter R, Obrist P (2003) Correlation of COX-2 and Ep-CAM overexpression in human invasive breast cancer and its impact on survival. Br I Cancer 88: 574-578

Steinbach G, Lynch PM, Phillips RK, Wallace MH, Hawk E, Gordon GB, Wakabayashi N, Saunders B, Shen Y, Fujimura T, Su LK, Levin B (2000) The effect of celecoxib, a cyclooxygenase- 2 inhibitor, in familial adenomatous polyposis. N Engl J Med 342: 1946-1952

Tan K-B, Yong W-P, Putti TC (2004) Cyclooxygenase-2 expression: a potential prognostic and predictive marker for high-grade ductal carcinoma in situ of the breast. Histopathology 44: 24-28

Tan P-H, Chuah K-L, Chiang G, Wong C-Y, Dong F, Bay B-H (2002) Correlation of $\mathrm{p} 53$ and CerbB2 expression and hormonal receptor status with clinicopathologic parameters in ductal carcinoma in situ of the breast. Oncol Rep 9: 1081-1086

Torrance CJ, Jackson PE, Montgomery E, Kinzler KW, Vogelstein B, Wissner A, Nunes M, Frost P, Discafani CM (2000) Combinatorial chemoprevention of intestinal neoplasia. Nat Med 6: $1024-1028$

Tsujii M, Kawano S, Tsuji S, Sawaoka H, Hori M, DuBois RN (1998) Cyclooxygenase regulates angiogenesis induced by colon cancer cells. Cell 93: 705-716

Tucker ON, Dannenberg AJ, Yang EK, Zhang F, Teng L, Daly JM, Soslow RA, Masferrer JL, Woerner BM, Koki AT, Fahey III TJ (1999) Cyclooxygenase-2 expression is up-regulated in human pancreatic cancer. Cancer Res 59: $987-990$

Williams CS, Tsujii M, Reese J, Dey SK, DuBois RN (2000) Host cyclooxygenase-2 modulates carcinoma growth. J Clin Invest 105: $1511-1513$

Woods JM, Mogollon A, Amin MA, Martinez RJ, Kock AE (2003) The role of COX-2 in angiogenesis and rheumatoid arthritis. Exp Mol Pathol 74: $282-290$

Zhao Y, Agarwal VR, Mendelson CR, Simpson ER (1996) Estrogen biosynthesis proximal to a breast tumor is stimulated by PGE2 via cyclic AMP, leading to activation of promoter II of the CYP19 (aromatase) gene. Endocrinology 137: 5739-5742 